\title{
'Esclavos españoles, indios y negros': notas para el estudio de las relaciones interétnicas en las cofradías religiosas del norte del Virreinato del Río de la Plata \\ 'Spanish, Indian and Black slaves': notes regarding the study of inter-ethnic relationships in the religious brotherhoods of the northern Viceroyalty of the Río de la Plata
}

\author{
Enrique Normando Cruz \\ Consejo Nacional de Investigaciones Científicas y Técnicas de la Argentina. San Salvador de Jujuy, Argentina
}

Resumen: En esta nota se presenta el estudio de las cofradías religiosas de las ciudades de Salta y Jujuy (ubicadas al norte del Virreinato del Río de la Plata y sur de Charcas), realizado a partir del análisis historiográfico comparativo y la contrastación con fuentes históricas inéditas. Se han considerado, en especial, los libros de las cofradías y las prácticas sociales de registro y funcionamiento, con los objetivos de identificar a los distintos grupos étnicos que las componían, y establecer cómo se desarrollaron las relaciones interétnicas en un contexto de dominación colonial.

Palabras-clave: Cofradías. Etnicidad. Jujuy. Salta. Argentina.

Abstract: This research note presents the study of the religious brotherhoods of the cities of Salta and Jujuy (located to the north of the Viceroyalty of the Río de la Plata and South of Charcas). The study was based on comparative historiographical analysis and its contrast with unpublished historical sources. Especially books of the brotherhoods and social practices of registration and operation have been taken into account, with the objective of identifying the composition of various ethnic groups and establishing how inter-ethnic relationships developed in a context of colonial domination.

Keywords: Brotherhoods. Ethnicity. Jujuy. Salta. Argentina.

CRUZ, Enrique Normando. 'Esclavos españoles, indios y negros': notas para el estudio de las relaciones interétnicas en las cofradías religiosas del norte del Virreinato del Río de la Plata. Boletim do Museu Paraense Emílio Goeldi. Ciências Humanas, v. 8, n. 2, p. 449-458, maio-ago. 2013.

Autor para correspondência: Enrique Normando Cruz. Centro de Estudios Indígenas y Coloniales. Otero 257, $1^{\circ}$ piso, oficina 3. San Salvador de Jujuy, Jujuy, Argentina.4600-S (profecruz@yahoo.com.ar).

Recebido em 18/10/2012

Aprovado em 11/06/2013

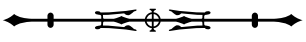




\section{INTRODUCCIÓN}

Las cofradías religiosas de América Hispana, fueron asociaciones conformadas por feligreses cristianos para el cumplimiento de tareas relacionadas con la vida y la muerte. Promovidas por el Estado y la Iglesia desde Nueva España hasta el Río de la Plata, albergaron la plenitud de la diversidad social y étnica de las sociedades urbanas y rurales.

En las ciudades de la gobernación del Tucumán norte del Río de la Plata y sur de Potosí -, las cofradías fueron abundantes' ${ }^{1}$ y acerca de las cuales se conoce como era la composición étnica, las autoridades políticas que en ellas desempeñaban oficios de gobierno, la religiosidad de los hermanos, el control y manejo de recursos y bienes, y la reconfiguración de la identidad étnica indígena; pero aún no se ha considerado de manera suficiente si favorecieron y de qué manera las relaciones interétnicas.

En esta nota se estudian las cofradías religiosas de las ciudades de Jujuy y Salta, urbes ubicadas en el medio del camino que vinculaba el puerto de Buenos Aires del Río de la Plata con los mercados mineros del Potosí. La elección del tema responde a que se trata de una institución colonial que permite apreciar, con base en el análisis de las constituciones y de las prácticas sociales de registro y funcionamiento, como se identificaba a los distintos grupos de españoles, indios, negros, mestizos y castas, y conocer las relaciones interétnicas en un contexto de dominación colonial cristiano que, entendemos hipotéticamente, hermanaba a todos en la esclavitud compartida de la virgen o el santo patrón de cofradía.
El análisis de las cofradías religiosas que funcionaron en la región entre fines del siglo XVIII y comienzos del XIX, ha sido posible por medio de un corpus empírico de documentación inédita de diverso tipo: libros de cofradías, testamentos e inventarios de bienes, libramientos de pagos, y letras patentes. Esta documentación ha permitido determinar el carácter abierto de estas asociaciones² ${ }^{2}$ y cómo ello posibilitó la integración interétnica porque no se controló de manera estricta el ingreso y permanencia en las cofradías, debido a la reducida extensión social de las cofradías gremiales ${ }^{3}$, y finalmente, por la común adscripción de familias completas de indígenas naturales y de españoles con su personal de servicio (indígenas y esclavos negros) ${ }^{4}$.

\section{LOS ESTUDIOS SOBRE LAS COFRADÍAS RELIGIOSAS EN EL RÍO DE LA PLATA}

Para referirse a las cofradías religiosas indígenas en los espacios urbanos coloniales del Tucumán, estudios anteriores plantean el concepto de región del 'Sur de Charcas' (De Luca, 2009), acuñado para los siglos XVI y XVII. Esta definición debe cambiarse por la del 'Norte del Río de la Plata', en virtud de la reorientación hacia el este del Chaco y el sur rioplatense que vivieron las ciudades del Tucumán a partir de la segunda mitad del siglo XVIII, como consecuencia de la ampliación de la colonización mercantilista ${ }^{5}$ hacia esas regiones.

Los estudios sobre las cofradías religiosas de la ciudad de Buenos Aires, capital del Virreinato del Río de la Plata, destacan especialmente las identidades políticas

1 En el curato rectoral de la ciudad de Jujuy funcionaron más de doce cofradías (Cruz, 1997), y una cantidad similar tenía la ciudad de Salta. En la ciudad de Córdoba, las cofradías religiosas también fueron numerosas (Martínez de Sánchez, 2006).

2 Se llama cofradías de carácter abierto, a las que en las constituciones y en la práctica de registro cofraderil no establecían condiciones de adscripción étnica, económica o cultural (Rumeu de Armas, 1981; Garland Ponce, 1994).

3 En las ciudades de Jujuy y Salta no se constituyeron gremios que habilitaran cofradías, a pesar de contar ambas ciudades con sectores de artesanos importantes (Raspi, 2001). La "endogamia cofraderil" era una característica de las cofradías gremiales, como la de los plateros de Lima (Paniagua Pérez, 1995).

4 La participación familiar en las cofradías religiosas fue algo común entre los hispanos de las grandes ciudades de México y Lima (Bazarte Martínez, 1989; Luque Alcaide, 1995).

5 Desde fines del siglo XVII, el espacio se configura desde Buenos Aires y Córdoba hacia las ciudades del Perú. A lo largo del siglo siguiente se viven procesos de cambio bajo la jurisdicción de la Audiencia de Charcas y luego de Buenos Aires (Assadourian, 1983).

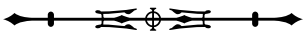


en torno a la revolución de mayo de 1810, el tipo de adscripción vecinal en parroquias rurales como Lujan, y el grado de religiosidad y devoción mariana en la misma parroquia y cabildo (Fogelman, 2000). Respecto del tema de las relaciones interétnicas, otros estudios han considerado solamente a las cofradías de esclavos negros, describiendo las formas de sociabilidad moderna, y cómo sirvieron para la reconstrucción de la identidad negra en el medio urbano (Rosal, 2006; González, 1995).

En relación a las otras ciudades del Virreinato del Río de la Plata, se conoce que en Mendoza la cofradía de Nuestra Señora del Carmen permitió la constitución de un espacio de poder para las mujeres españolas (Maurin, 2001); y en la importante ciudad de Córdoba, se ha estudiado en detalle las cofradías de españoles situadas en los conventos de las órdenes e iglesias parroquiales, describiéndose la religiosidad, los sistemas de cargos y de manejo de recursos, y el significado de la muerte en la determinación del espacio sepulcral (Martínez de Sánchez, 1999, 2005, 2006, 2007).

En los distritos de Jujuy y Salta, era mayor la cantidad y variedad étnica de las cofradías religiosas. Un estudio general sobre historia eclesiástica de Jujuy entre los siglos $X V I$ al $X X$, señala la existencia de cofradías religiosas desde el mismo momento de la fundación de la ciudad de Jujuy en 1593. Otro estudio, de manera pionera y con base en los muy bien salvaguardados libros de cofradía, describe las autoridades, bienes y recursos de las cofradías indígenas de Humahuaca (Vergara, 1942; Márquez Miranda, 1933). La utilización de los mismos libros es lo que ha permitido conocer los procesos étnicos de las cofradías rurales de indios (Zanolli, 2004); y gracias a la catalogación de los documentos del Obispado de Jujuy, se localizaron los libros de cofradías de españoles del curato rectoral, en las que existió un paralelismo entre autoridades capitulares y de cofradías (Estruch, 2009). También distintos registros de cofradías de indios y negros, permitieron saber cómo se mestizaron los indígenas urbanos (Cruz, 2007), y se empoderaron las mujeres españolas e indígenas en las cofradías y fiestas religiosas (Cruz, 2005).

Respecto de las cofradías de la ciudad de Salta, si bien se las menciona en investigaciones sobre la sociedad, las elites, las capellanías, y la familia en la ciudad (Caretta y Zacca, 2007; Mata de López, 2000), sólo se ha estudiado la participación de los españoles en la cofradía del Santísimo Sacramento (Quinteros, 2008).

\section{METODOLOGÍA Y FUENTES}

Los estudios históricos sobre las cofradías religiosas que funcionaron en el Virreinato del Río de la Plata en el siglo XVIII han considerado la clasificación establecida para las cofradías y hermandades de los reinos peninsulares hispanos, que se aplica de manera pertinente para el estudio de estas asociaciones en tránsito de la caridad y acción social del Antiguo Régimen, a la beneficencia y política social de la Modernidad (Rumeu de Armas, 1981).

En este caso, se ha elegido la comparación histórica (Mörner, 1994) de las cofradías del Tucumán, con las cofradías de españoles y de indios de los distritos andinos de la sierra peruana, Lima, Sechura, Chile, México o Michoacán (Celestino y Meyers, 1981; Diez Hurtado, 1994; Garland Ponce, 1994; Bechtloff, 1996; Valenzuela Márquez, 2010), porque son similares en la composición multiétnica y social, y en el desarrollo prevalente de tareas vinculadas al control de recursos comunitarios y a prácticas de caridad cristiana hipanocolonial.

Los objetivos del trabajo de investigación son la identificación de las cofradías que funcionaron en las ciudades de Jujuy y de Salta, y la determinación precisa de su composición social y étnica, considerando documentación histórica del tipo libros de colecturía y de constituciones de las asociaciones. Como algunas cofradías no tenían estos documentos, se ha completado el relevamiento a partir de las referencias a cofradías en donaciones, reconocimientos de acreencias, y recibos de pagos, ubicados en una base

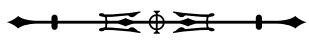


de datos de testamentos e inventarios de bienes del siglo XVIII ${ }^{6}$.

\section{LAS CIUDADES DE JUJUY Y SALTA Y LAS COFRADÍAS RELIGIOSAS}

La ciudad de San Salvador de Jujuy fue fundada en 1593 , y hasta 1690 era solo una estación de paso en el tráfico que aceleradamente empezaba a desarrollarse a partir del auge de la minería potosina y de otros lugares vecinos. Esta situación cambió a fines del siglo XVII, cuando se instaló la aduana seca y se transformó de lugar de paso a lugar de asentamiento de comerciantes de giro regional, participando, de esta manera, en el tráfico alternativamente legal e ilegal establecido entre Buenos Aires y Lima, con las importantes estaciones de paso de Arequipa, Potosí, Salta, Tucumán y Córdoba ${ }^{7}$.

Se ha constatado que, desde inicios del siglo XVII, funcionaron en la ciudad de Jujuy cofradías religiosas, y algunas de ellas continuaron hasta por lo menos mediados del siglo XIX. Las hubo de todo tipo y variedad, por ejemplo en el casco urbano de la ciudad funcionaron las cofradías étnicas de San Pedro, de indios naturales, y de San Benito de Palermo, de negros y mulatos, a la cual también pertenecían blancos españoles. Este último grupo participaba especialmente de las cofradías de Nuestra Señora del Carmen y del Santísimo Sacramento, a la que se adscribían de manera especial todas las autoridades del cabildo $^{8}$. Otras cofradías más pequeñas eran las surgidas para administrar las mandas forzosas (Redención de Cautivos Cristianos y Ánimas Benditas del Purgatorio9), y también encontramos cofradías de devoción familiar, como la de Nuestra Señora del Rosario ${ }^{10}$.

En la parte rural del distrito de Jujuy (Puna y Quebrada de Humahuaca), fueron numerosas las cofradías de indios. A diferencia de las cofradías urbanas, que pusieron el acento en las tareas de administración de la caridad, estas asociaciones indígenas favorecieron el control de bienes y recursos comunitarios para el reforzamiento de la autoridad cacical como parte de procesos de adaptación en resistencia respecto de los curas y doctrineros (Cruz, 2006; Zanolli, 2008).

La ciudad de Salta fue similar a Jujuy en la conformación y rol en la carrera mercantil regional. La diferencia estuvo en la magnitud de los negocios. Desde el siglo XVII y de manera acelerada a fines del XVIII, Salta cumplió el importante rol de estación de tránsito para las ferias de mulas y campos de invernada, y funcionó también como centro consumidor y re-exportador de efectos de Castilla introducidos desde Buenos Aires, y de 'tocuyos' (telas burdas de algodón) ingresados desde el Alto Perú (SánchezAlbornoz, 1965). En la segunda mitad del siglo XVIII y con la recuperación de la minería altoperuana, la ciudad creció hasta constituirse en la más importante urbe de la región.

Las cofradías de Salta eran tan numerosas como las de Jujuy e igualmente albergaban distintos grupos étnicos. En la iglesia matriz funcionaba la cofradía de San Pedro, que recibía especialmente a religiosos españoles; la de Jesús Nazareno enterraba, además de españoles, a indios y esclavos. Otras cofradías de la matriz eran las de Nuestra Señora del Rosario, Santísimo Sacramento y

\footnotetext{
6 La base de datos comprende 360 documentos del tipo testamentos, codicilos e inventarios de bienes en el período 1690-1800, localizados en los archivos locales de la provincia de Jujuy, lo que ha permitido identificar a las cofradías religiosas que no dejaron registro documental del tipo libro de constituciones. Queda por realizar una tarea similar para el distrito de Salta, respecto del cual se ha considerado a las cofradías que poseían libros de colecturía y de constituciones, y que son mencionadas en referencias historiográficas.

7 Acerca del desarrollo del mercantilismo en Jujuy en el siglo XVIII, confróntese Palomeque (1994) y Santamaría (1999).

8 "Libro de la cofradía del Santísimo Sacramento, Jujuy, 1660-1775". Archivo del Obispado de Jujuy, caja 26, legajo 10.

9 Llamamos cofradías de mandas forzosas a las que se constituyen para administrar los fondos generados por las donaciones obligatorias testamentarias. En Jujuy encontramos a las cofradías de Redención de Cautivos Cristianos, Santos Lugares de Jerusalén y Ánimas Benditas del Purgatorio (Cruz, 2003).

10 La cofradía de Nuestra Señora del Rosario era una asociación conformada por y para el uso exclusivo de las familias españolas de los Tijera y Goyechea, vecinos de la ciudad de Jujuy. "Carta de fundación de la cofradía de Nuestra Señora del Rosario, Jujuy, 1692- 1695". Archivo de Tribunales de Jujuy, carpeta 23, legajo 704.
}

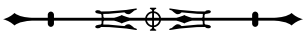


Ánimas Benditas, que contaban con cofrades de diverso origen étnico.

En el convento de San Francisco tenían sede las cofradías de Nuestra Señora de la Candelaria y la de San Benito de Palermo; y en la iglesia de los jesuitas la de San Baltasar, dos últimas devociones características de negros y mulatos. En el convento de las carmelitas descalzas funcionó la cofradía de Nuestra Señora del Carmen (Quinteros, 2008), y se menciona una cofradía de los Santos Lugares ${ }^{11}$, pero sin precisar en donde tenía su sede. Finalmente, aunque algunos estudios registran su existencia, se descarta que funcionara en el casco urbano de Salta una cofradía del rey de Bastos ${ }^{12}$, por tratarse casi con seguridad de la referencia documental, en tono de amonestación, a la costumbre condenada y perseguida por las autoridades eclesiásticas del juego en los claustros de iglesias y conventos ${ }^{13}$.

\section{LA DIVERSIDAD ÉTNICA EN LAS COFRADÍAS RELIGIOSAS DE JUJUY Y SALTA}

Entre las ciudades del Virreinato del Río de la plata, Jujuy y Salta se caracterizaban por la preeminencia de la población indígena nativa y el importante peso demográfico en los cascos urbanos de las castas de negros respecto de los blancos hispanos (Tabla 1).

La sociedad colonial tucumana se caracterizó, en este período, por la multietnicidad, multiculturalidad y multiplicidad de niveles sociales, jerárquicamente estructurados, incluso internamente. La multietnicidad refiere a la existencia de diferentes grupos de población nativa (indígenas altoandinos conviviendo con indígenas de las tierras selváticas del Chaco), y también a los distintos orígenes regionales de los peninsulares. Como resultado de la coexistencia de estos dos grupos mayores, se encontraban los mestizos, entre los cuales debemos incluir el producto de las uniones de indios y españoles, al de distintos grupos étnicos entre si y a los de éstos con los africanos, quienes ya para esta época constituían un componente demográfico de peso creciente (Lorandi, 2008, p. 56).

Por eso no es extraño que en las cofradías religiosas se recibieran con facilidad, como "hermanos esclavos", a blancos hispanos, negros, mulatos, pardos e indígenas, sin contemplar la distinción política entre la "República de indios" y la "República de españoles", o la distinción étnica y social entre "blancos" y las "castas", en la recepción del nuevo cofrade. Esto es lo que sucedía en la cofradía de Nuestra Señora del Carmen de Jujuy, que entre los años 1737 y 1833 recibió y registró como cofrades a españoles, negros y mulatos, indígenas libres y de servicio (Tabla 2$)^{14}$. Aunque no se distinguía a los que ingresaron a la cofradía por el pago que realizaban, pues todos abonaban la misma cantidad de 1 a 2 reales de ingreso, en la consignación del libro si se establecía el grupo étnico o social al que pertenecía cada individuo: españoles, indios libres e indios de servicio, negros esclavos, de servicio y libres, mestizos, cholos y mulatos libres y esclavos ${ }^{15}$. En cuanto al gobierno de la cofradía, el cuadro de autoridades era reducido: se elegía anualmente un mayordomo o prioste varón y una mujer, para cada uno de los "cuerpos de esclavos de la virgen"16.

\footnotetext{
11 Probablemente se trate, como en Jujuy, de una cofradía que se conforma con las mandas forzosas, caracterizadas por no contar con capilla o altar propio, y en las cuales la institucionalización asociativa se limitaba a la elección de una sola autoridad que quedaba a cargo de los fondos económicos y nada más (Cruz, 2003).

12 La referencia a la existencia de esta 'cofradía' figura en Toscano (1906).

13 La pauta de prohibición al juego en los espacios sacros cristianos aparece de manera recurrente en las 'Letras patentes', publicadas en los libros de fábrica del convento de San Francisco de Jujuy. "Libro de letras patentes del convento de San Francisco de Jujuy, letras patentes de 1720 a 1788, Jujuy". Archivo del Convento de San Francisco de Jujuy.

14 "Libro de asientos de los hermanos de la cofradía de Nuestra Señora del Carmen", 1736- 1813, Jujuy (en adelante Libro de la cofradía del Carmen). Archivo del Obispado de Jujuy, caja 27, legajo 12 (10-1), 155 folios.

15 Libro de la cofradía del Carmen. Archivo del Obispado de Jujuy, caja 27, legajo 12 (10-1), 155 folios.

16 Libro de la cofradía del Carmen. Archivo del Obispado de Jujuy, caja 27, legajo 12 (10-1), 155 folios.
}

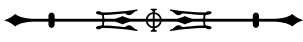


Tabla 1. Composición étnica de la población del Tucumán (Maeder, 1984, p. 10).

\begin{tabular}{c|c|c|c|c}
\hline Distrito & $1778-1779$ & Blancos & Indios & Gente de color \\
\hline Córdoba & 40.203 & $46 \%$ & $10 \%$ & $44 \%$ \\
\hline Santiago del Estero & 15.456 & $14 \%$ & $32 \%$ & $54 \%$ \\
\hline Tucumán & 20.104 & $16 \%$ & $20 \%$ & $64 \%$ \\
\hline Salta & 11.565 & $27 \%$ & $27 \%$ & $46 \%$ \\
\hline Jujuy & 13.619 & $5 \%$ & $82 \%$ & $13 \%$ \\
\hline Catamarca & 13.315 & $30 \%$ & $18 \%$ & $52 \%$ \\
\hline La Rioja & 9.723 & $26 \%$ & $54 \%$ & $20 \%$ \\
\hline
\end{tabular}

Tabla 2. Composición étnica de la cofradía del Carmen de Jujuy.

\begin{tabular}{c|c|c|c|c|c|c|c|c|c|c}
\hline Grupo étnico & Españoles & \multicolumn{2}{|c|}{ Indios } & \multicolumn{3}{c|}{ Negros } & \multicolumn{3}{c|}{ Mestizos } & \multicolumn{2}{c}{ Mulatos } \\
\hline Categoría social & & Servicio & Libres & Esclavos & Servicio & Libres & Mestizos & Cholos & Libres & Esclavos \\
\hline Hombres & 63 & 3 & 2 & 27 & - & 2 & 3 & - & - & - \\
\hline Mujeres & 203 & 4 & 3 & 15 & 1 & 1 & 4 & 4 & 6 & 8 \\
\hline
\end{tabular}

Los indígenas y mestizos de indios de la parte urbana de la ciudad de Jujuy también podían elegir a la cofradía de San Pedro de naturales ${ }^{17}$, la única cofradía urbana de indios en una ciudad que, en los años finales del siglo XVIII, tenía entre un $25 \%$ y un $30 \%$ de población indígena, sobre un total de 3.885 habitantes ${ }^{18}$. La cofradía de San Pedro recibía como cofrades a mestizos e "indios" (indígenas del Chaco), y especialmente a "naturales", como se llamaba a los indígenas de tradición agroalfarera altoandina, que elegían la asociación guiados por criterios de identidad étnica y no social, como en la del Carmen, en la que el registro señalaba de manera taxativa la relación social de producción correspondiente: "En dies y seis de junio de mil setecientos nobenta y cinco asente en esta Santa cofradía de (Nuestra Señora) del Carmen a Maria Flores Yndia libre sirviente de la Beata"19.
La integración étnica de los indígenas que pertenecían a la cofradía de San Pedro era alta, porque la mayoría de los que se adscribían como cofrades también desempeñaban alguno de los oficios de gobierno. En la elección de autoridades y registro de cofrades del año 1756, de las setenta y tres personas anotadas, cincuenta y dos se registran como autoridades de la cofradía ${ }^{20}$. La asunción familiar y comunitaria del gobierno de la asociación es un ejemplo de que, de esa manera, se volvieron a instituir regímenes de autoridad étnica rural, probablemente devaluados como consecuencia de la vida urbana y mestiza, desarrollándose procesos similares a los de la población indígena rural que migró a las ciudades de Charcas y de Santiago de Chile, en el siglo XVII, quienes también conformaron cofradías urbanas de indios para mantener los vínculos comunitarios y las relaciones familiares campesinas (Saignes, 1987; Valenzuela Márquez, 2010).

\footnotetext{
17 Para determinar la composición de esta cofradía, se analizó el "Libro de colecturía de la cofradía”, que indica que se eligen autoridades, registran cofrades, y se entregan, recolectan y reciben pagos desde 1752 a 1776. Archivo del Obispado de Jujuy, Libro de Matrimonios, Catedral (1693-1836), n. 4, Naturales.

18 "Censo de la provincia 1778-1779". Archivo Histórico de Jujuy, Archivo Capitular de Jujuy.

19 Libro de la cofradía del Carmen. Archivo del Obispado de Jujuy, folio 36.

20 "Libro de colecturía de la cofradía de San Pedro de naturales", Jujuy, 1752-1776 (en adelante Libro de cofradía de San Pedro de Naturales). Archivo del Obispado de Jujuy, Libro de Matrimonios, Catedral (1693-1836), n. 4, Naturales.
}

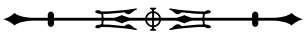


La composición étnica diversa era también una característica en las cofradías del Santísimo Sacramento de las ciudades de Jujuy y Salta. Además de contar con los miembros del cabildo como autoridades ${ }^{21}$, recibían como hermanos a indígenas libres, mulatos, negros libres y esclavos ${ }^{22}$. Las personas que en Salta se adscribían a la cofradía del Santísimo Sacramento debían, de acuerdo a las constituciones, hacer el pago a título de limosna de una suma de dinero fija, que podía ser remplazada y mejorada con la entrega de servicios o bienes de diverso tipo: cera, adornos para la devoción, trabajo de recolección de bienes en el casco urbano de la ciudad ${ }^{23}$.

La cofradía del Santísimo Sacramento de la ciudad de Salta se asemeja a la cofradía del Carmen de Jujuy en la apertura social y étnica de los cofrades, encontrándose a indígenas y esclavos negros, junto a españoles y sus familias. Los esclavos se registraban en la cofradía cuando lo hacían los amos, como el caso del esclavo del mayordomo que realizó el traslado del libro original, el presbítero Miguel Ángel Visuara ${ }^{24}$. Respecto de los indios, el reglamento constituyente de la cofradía estipulaba que podían pagar menos que los dos pesos solicitados a los otros cofrades, especificándose, en las mismas constituciones, que no debía "ponérseles problemas" para el ingreso y participación en la cofradía 25 .

La adscripción mayoritaria en la cofradía del Santísimo Sacramento de Salta era de españoles. En el marco de este tipo de reconocimiento de la diversidad e integración, los más importantes comerciantes salteños de giro local y regional pertenecían a ella. De esta manera, encontramos que, en el registro como cofrade y en la participación como autoridades de la asociación, se reforzaba la posición social y se atenuaba el carácter de integración, que, por la composición multiétnica, parece haber desarrollado la cofradía (Tablas 3 y 4).

Tabla 3. Composición étnica de las cofradías de Jujuy (siglo XVIII).

\begin{tabular}{|c|c|c|}
\hline Devoción & Sede & Grupo social \\
\hline Nuestra Señora del Carmen & Iglesia Matriz & $\begin{array}{c}\text { Españoles, indios, negros y } \\
\text { mulatos esclavos y pardos libres }\end{array}$ \\
\hline San Pedro & Iglesia Matriz & Indígenas \\
\hline Ánimas Benditas del Purgatorio & Iglesia Matriz & $\begin{array}{l}\text { Españoles, mestizos, } \\
\text { indios y negros }\end{array}$ \\
\hline Santísimo Sacramento & Iglesia Matriz & Españoles y mestizos \\
\hline Santos Lugares de Jerusalén & Iglesia del convento de San Francisco & $\begin{array}{l}\text { Españoles, mestizos, } \\
\text { castas e indios }\end{array}$ \\
\hline San Benito de Palermo & Iglesia del convento de San Francisco & $\begin{array}{l}\text { Negros y mulatos esclavos, } \\
\text { pardos libres y españoles }\end{array}$ \\
\hline Nuestra Señora del Rosario & Iglesia del convento de San Francisco & Españoles \\
\hline
\end{tabular}

21 Siendo ambas ejemplo de que estas asociaciones constituyeron una fuente importante en la obtención de la honorabilidad y prestigio inherente al poder de la elite colonial (Mayer, 2000).

22 "Libro de la cofradía del Santísimo Sacramento de Salta" (en adelante Libro de la cofradía del Santísimo Sacramento de Salta). Archivo Histórico de Salta, Fondo libros copiadores del Cabildo de Salta; y "Libro de la cofradía del Santísimo Sacramento, Jujuy". Archivo del Obispado de Jujuy, caja 26, legajo 10.

23 "Libro en que se lleva la razón de las limosnas recaudadas y gastos del culto del Señor Sacramentado, elección de diputados, y asiento de los cofrades, para el gobierno distributivo y económico de dicha cofradía"; Libro de la cofradía del Santísimo Sacramento de Salta. Archivo Histórico de Salta.

${ }^{24}$ Libro de la cofradía del Santísimo Sacramento de Salta. Archivo Histórico de Salta.

${ }^{25}$ Libro de la cofradía del Santísimo Sacramento de Salta. Archivo Histórico de Salta.

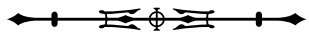


Tabla 4. Composición étnica de las cofradías de Salta (siglo XVIII).

\begin{tabular}{c|c|c}
\hline Devoción & Sede & Grupo social \\
\hline Jesús Nazareno & Iglesia Matriz & Españoles, indios y negros esclavos \\
\hline San Pedro & Iglesia Matriz & Españoles, especialmente religiosos \\
\hline Ánimas Benditas del Purgatorio & Iglesia Matriz & Españoles, mestizos, indios y negros \\
\hline Santísimo Sacramento & Iglesia Matriz & Españoles, mestizos y negros \\
\hline Nuestra Señora del Rosario & Iglesia del convento de San Francisco & Españoles \\
\hline Nuestra Señora de la Candelaria & Iglesia del convento de San Francisco \\
\hline San Benito de Palermo & Iglesia del convento de San Francisco & Negros y mulatos esclavos, \\
\hline Nuestra Señora del Carmen libres y españoles
\end{tabular}

\section{CONSIDERACIONES FINALES}

El registro de las personas que ingresaban a la cofradía de Nuestra Señora del Carmen de Jujuy era desordenado. Cada nuevo cofrade se asentaba a continuación del siguiente, 'sin orden ni concierto', por lo que a mitad del libro de la asociación, el capellán a cargo del cogobierno de la asociación dispuso que los mayordomos debían tratar, de ahí en adelante, de anotar a los nuevos cofrades de la manera siguiente:

A fojas 4 se asientan los Sacerdotes Esclavos, de esta Santa Cofradía.

A fojas 10 los Esclavos españoles.

A fojas 20 las Señoras esclavas.

A fojas 30 los esclavos de la gente común

Yndios, negros y mulatos.

A fojas 50 los esclavos de el estado común

Yndios, negros y mulatos ${ }^{26}$.

La recomendación no fue respetada pues continúa anotándose el ingreso y pago de limosnas de los cofrades en un registro común, sin distinciones, y con el cobro igualitario de la limosna de ingreso.

En la cofradía de San Pedro de naturales de la ciudad de Jujuy, esta recomendación no existía. Los indígenas de diverso origen étnico (altoandino y selváticos del Chaco) y los mestizos se integraron e hispanizaron en la asociación mediante el ejercicio de los oficios de gobierno, en la realización con brillo y estruendo de las fiestas religiosas cristianas, y en la construcción y mantenimiento de un cementerio propio para los hermanos ${ }^{27}$.

Similar composición e integración multiétnica presentaron las cofradías de la ciudad de Salta, en especial la del Santísimo Sacramento, que admitía como cofrades a hispanos miembros del cabildo y a comerciantes que se registraban junto a sus familias. Lo mismo podían hacer los esclavos e indígenas de la ciudad, quienes, además de aportar menos dinero por el ingreso, "no debían ser molestados" en la participación de la asociación.

Esta primera aproximación al estudio comparativo de las cofradías religiosas indianas permite reafirmar el carácter particular de esta asociación colonial, deslingándola de las tareas de beneficencia que algunas desarrollaran en el siglo XIX; y concluir que en esta región del Virreinato del Río de la Plata, las cofradías se encargaron, especialmente, de la integración y mestizaje de españoles, negros, mulatos y pardos, e indios libres y de servicio, en un marco religioso del que no debe haber estado ausente el conflicto, pero que al parecer

\footnotetext{
${ }^{26}$ Libro de la cofradía del Carmen, foja 17. Archivo del Obispado de Jujuy.

${ }^{27}$ Libro de cofradía de San Pedro de Naturales. Archivo del Obispado de Jujuy.
}

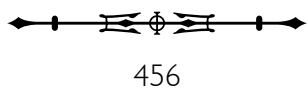


abría más bien la vía a la integración étnica. De allí que el clero hispano, los españoles comerciantes y sus esposas, los campesinos y arrieros indios, los esclavos y sirvientes negros y mulatos, y los trabajadores urbanos de la plebe de mestizos y las castas, fueran todos 'esclavos', y por ello 'hermanos' en alguna cofradía religiosa.

\section{REFERENCIAS}

ASSADOURIAN, Carlos Sempat. El sistema de la economía colonial: mercado interno. Regiones y espacio económico. México: Instituto de Estudios Peruanos, 1983.

BAZARTE MARTÍNEZ, Alicia. Las cofradías de españoles en la ciudad de México (1526-1869). México: Universidad Autónoma Metropolitana, 1989.

BECHTLOFF, Dagmar. Las cofradías de Michoacán durante la época colonial. La religión y su relación política y económica en una sociedad intercultural. México: El Colegio de Michoacán, 1996.

CARETTA, Gabriela; ZACCA, Isabel. Lugares para la muerte en el espacio meridional andino, Salta en el siglo XVIII. Memoria Americana, Buenos Aires, n. 15, p. 135-154, 2007.

CELESTINO, Olinda; MEYERS, Albert. Las cofradías en el Perú: región central. Frankfurt: Verlag Klaus Dieter Vervuert, 1981.

CRUZ, Enrique N. Una cofradía urbana de indios a fines de la colonia: San Pedro de Naturales (Jujuy - Río de la Plata). Revista Andina, Cuzco, n. 44, p. 227-248, 2007.

CRUZ, Enrique N. Poder y relaciones sociales en curatos de indios. El curato de Cochinoca en el siglo XVIII (Puna de Jujuy - Argentina). Hispania Sacra, Madrid, v. 58, n. 117, p. 355-381, 2006.

CRUZ, Enrique N. Mujeres en la colonia. Dominación colonial, diferencias étnicas y de género en cofradías y fiestas religiosas en Jujuy, Río de la Plata. Anthropologica, v. 23, n. 23, p. 127150, 2005.

CRUZ, Enrique N. Cofradía, montepíos y hospitales en la sociedad jujeña del siglo XVIII. 2003. 350 f. Tesis (Doctorado en Historia y Antropología) - Universidad de Sevilla, Sevilla, 2003.

CRUZ, Enrique N. De igualdades y desigualdades: cofradías en el Jujuy colonial. Anuario del Instituto de Estudios Histórico Sociales, Tandil, n. 12, p. 293-305, 1997.

DE LUCA, María Candela. Las cofradías de indios en el territorio de Charcas (siglo XVIII): balance historiográfico y nuevas propuestas de análisis. In: JORNADA NACIONAL DE HISTORIA SOCIAL, 2., 2009, Córdoba. Anales... Córdoba: UNLP/CONICET, 2010. 1 CD-ROM.
DIEZ HURTADO, Alejandro. Fiestas y cofradías: asociaciones religiosas e integración en la historia de la comunidad de Sechura (siglos XVII al XX). Piura: CIPCA, 1994.

ESTRUCH, Dolores. Fundar, gobernar y rezar. Una aproximación a los vínculos entre sociedad, política y religión en el Jujuy colonial (1656-1776). Runa, Buenos Aires, v. 30, n. 1, p. $61-$ 78, 2009.

FOGELMAN, Patricia A. Una cofradía mariana urbana y otra rural en Buenos Aires a fines del período colonial. Andes, Salta, n. 11, p. 179-207, 2000.

GARLAND PONCE, Beatriz. Las cofradías en Lima durante la colonia. Una primera aproximación. In: RAMOS, Gabriela (Comp.). La venida del reino. Religión, evangelización y cultura en América, Siglos XVI-XX. Cuzco: Centro de Estudios Regionales Andinos Bartolomé de Las Casas, 1994. p. 199-228.

GONZÁLEZ, Ricardo. Aseados y devotos. Tres cofradías de negros en Buenos Aires colonial. In: GONZÁLEZ, Ricardo (Org.). Imágenes de la ciudad capital: arte en Buenos Aires en el siglo XVIII. La Plata: Minerva, 1995.

LORANDI, Ana M. Poder central, poder local: funcionarios borbónicos en el Tucumán colonial. Un estudio de Antropología Política. Buenos Aires: Editorial Prometeo, 2008.

LUQUE ALCAIDE, Elisa. La cofradía de Aránzazu de México (1681-1799). Pamplona: Ediciones Eunate, 1995.

MAEDER, Ernesto. La formación de la sociedad Argentina desde el siglo XVI hasta mediados del XVIII. Resistencia: Instituto de Investigaciones Geohistóricas, 1984.

MÁRQUEZ MIRANDA, Fernando. La primitiva Iglesia de Humahuaca y sus cofradías coloniales. Contribución al estudio de las instituciones económico-religiosas. Boletín del Instituto de Investigaciones Históricas, Buenos Aires, v. 16, p. 113-155, 1933.

MARTÍNEZ DE SÁNCHEZ, Ana María. Los jesuitas: sus cofradías y congregaciones. Córdoba: EDUCC, 2007.

MARTIíNEZ DE SÁNCHEZ, Ana María. Cofradías y obras pías en Córdoba del Tucumán. Córdoba: EDUCC, 2006.

MARTÍNEZ DE SÁNCHEZ, Ana María. "La resurrección de los muertos": significado del espacio sepulcral. Hispania Sacra, v. 57 , n. 115, p. 109-140, 2005.

MARTÍNEZ DE SÁNCHEZ, Ana María. Cofradías asentadas en la iglesia de la Compañía de Jesús. Córdoba: Prosopis Editora, 1999.

MATA DE LÓPEZ, Sara. Tierra y poder en Salta: el Noroeste Argentino en vísperas de la independencia. Sevilla: Diputación de Sevilla, 2000.

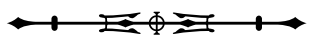


MAURIN, María del Carmen. Los hermanos cofrades de Nuestra Señora del Carmen en San Juan de la Frontera, siglo XVIII. In: JORNADAS INTER-ESCUELAS Y/O DEPARTAMENTOS DE HISTORIA, 7., 2001, Salta. Anales... Salta: Universidad Nacional del Comahue, 2001. 1 CD-ROM.

MAYER, Alicia. Las corporaciones guadalupanas: centros de integración "universal" del catolicismo y fuentes de honorabilidad y prestigio. In: PASTOR, María Alba; MAYER, Alicia (Coords.). Formaciones religiosas en la América colonial. México: Universidad Nacional Autónoma de México, 2000. p. 179-201.

MÖRNER, Magnus. En torno al uso de la comparación en el análisis histórico de América Latina. Jahrbuch für Geschichte von Staat, Colonia, n. 31, p. 373-390, 1994.

PALOMEQUE, Silvia. Intercambios mercantiles y participación indígena en la "Puna de Jujuy" a fines del período colonial. Andes, Salta, v. 6, p. 13-48, 1994.

PANIAGUA PÉREZ, Jesús. Cofradías limeñas: San Eloy y la Misericordia (1597-1733). Anuario de Estudios Americanos, Sevilla, v. 52, n. 1, p. 13-35, 1995.

QUINTEROS, Víctor E. Las cofradías en la ciudad de Salta hacia fines del siglo XVIII. In: JORNADA DE HISTORIA DE LA IGLESIA, 2., Tucumán, 2008. Anales... Salta: UNSa/UNSTA/UNT/UCSE/ Arquidiócesis de Tucumán, 2008. 1 CD-ROM.

RASPI, Emma T. El mundo artesanal de dos ciudades del norte argentino. Salta y Jujuy, primera mitad del siglo XIX. Anuario de Estudios Americanos, Sevilla, v. 58, n. 1, p. 161-183, 2001.

ROSAL, Miguel A. Manifestaciones de la religiosidad católica afroporteña (1750-1860). Idea Viva, Buenos Aires, n. 22, p. 78-84, 2006.

RUMEU DE ARMAS, Antonio. Historia de la previsión social en España: cofradías, gremios, hermandades, montepíos. Barcelona: Ediciones El Albir, 1981.
SAIGNES, Thierry. Ayllus, mercado y coacción colonial: el reto de las migraciones internas en Charcas (siglo XVII). In: HARRIS, Olivia; LARSON, Brooke; TANDETER, Enrique (Comp.). La participación indígena en los mercados surandinos. Estrategias y reproducción social. Siglos XVI a XX. La Paz: CERES, 1987. p. 111-158.

SÁNCHEZ-ALBORNOZ, Nicolás. La saca de mulas de Salta al Perú 1778-1808. Annuario del Instituto de Investigaciones Históricas, Rosario, n. 8, p. 261-312, 1965.

SANTAMARÍA, Daniel J. Mercaderes, tenderos y prestamistas. La mercantilización de la economía jujeña (1690-1730). Anuario del IEHS, Tandil, n. 14, p. 437-469, 1999.

TOSCANO, Jaime. El primitivo obispado del Tucumán y la iglesia de Salta. Buenos Aires: Imprenta de M. Biedma e hijo, 1906. Tomo 1.

VALENZUELA MÁRQUEZ, Jaime. Devociones de inmigrantes. Indígenas andinos y plurietnicidad urbana en la conformación de cofradías coloniales (Santiago de Chile, siglo XVII). Historia, Santiago, v. 43, n. 1, p. 203-244, 2010.

VERGARA, Miguel Ángel. Estudios sobre historia eclesiástica de Jujuy. Tucumán: Universidad Nacional de Tucumán, 1942.

ZANOLLI, Carlos Eduardo. Entre la coerción, la oportunidad y la salvación. Las cofradías de indios de San Antonio de Humahuaca. Siglos XVII y XVIII. Andes, Salta, n. 19, p. 345-367, 2008.

ZANOLLI, Carlos Eduardo. Santa Bárbara, una cofradía de indios en San Antonio de Humahuaca (1713-1785). Anuario de Historia Regional y de las Fronteras, Bucamaranga, v. 9, n. 1, p. 87-109, 2004.

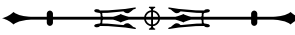

